\title{
Biofuel from Hydroprocessing Fish Oil
}

\author{
RALUCA ELENA DRAGOMIR, PAUL ROSCA* \\ Petroleum - Gas University of Ploiesti, 39 Calea Bucuresti,100520, Ploiesti, Romania
}

This paper deals with the hydroprocessing of Fish Oil (FO) as a source to produce biofuel. The hydrotreating experiments were performed at $380^{\circ} \mathrm{C}$ and 50bar pressure over the $\mathrm{CoMo}_{\mathrm{A}} \mathrm{Al}_{2} \mathrm{O}_{3}$ and CoMoRe/Al $\mathrm{O}_{3}$ catalysts. Through hydrogenation of double bonds and carboxyl groups of Fatty Acids (FAs), accompanied by secondary hydrocracking and isomerization reactions, there results a mixture of normal \& isoparaffin with 13-22 carbon atoms per molecule with physicochemical characteristics similar to diesel fuel. The hydrotreatment of Straight Run Gas Oil (SRGO) mixed with 5\% and 10\% (FO) was also studied. The research focuses on the influence of the SRGO-FO ratio and of the catalyst type on the yields and the physiochemical properties of the obtained biofuel. The results show that the hydrotreatment of FO and of SRGO-FO mixtures is an alternative for biofuel production with characteristics similar to diesel fuel.

Keywords: Fish oil; biofuel, hydroprocessing, hydroteating, straight run gas oil, pour point

The largest part of world energy consumption is ensured by fossil fuels: coal, oil and natural gas which are nonrenewable resources with a high rating of depletion in the following 50 to 100 years [1-3]. The increasing consumption of fossil fuels has a negative impact not only on remaining hydrocarbon reserves, but also on environmental pollution by high grade $\mathrm{NO}_{\mathrm{x}}, \mathrm{CO}_{2}$ and $\mathrm{SO}_{\mathrm{x}}$ emissions which result from fossil fuel combustion [4-7].

Fossil fuels replacement with Renewable Energy Sources (RES) has mainly gained in importance in recent years [1,8-10]. All the EU countries have decided to increase the biofuel content in commercial fuels for cars from $2 \%$ in 2005 to $5.75 \%$ in 2010 and $10 \%$ in 2020 without affecting food needs for the population [11,12]. In 2020 Romania advances its targets to $24 \%$ RES on gross energy consumption; respectively $10 \%$ as biofuels for transportation and from 2030 the target is $27 \%$ RES on total energy consumption, an increase of $27 \%$ in energy efficiency and a reduction of GHG emissions by $40 \%$ as compared to 1990 [13].

Vegetable oils, animal fats, waste cooking oil and waste of animal origin are the most important RES used to produce biofuels for diesel engines.

Due to high viscosity, lower oxidation stability, lower volatility and particle emissions, vegetable oils cannot be used directly as diesel fuels $[14,15]$.

Numerous technologies based on physical phenomena (dilution and emulsification) or chemical transformations (transesterification, hydrotreating, hydrocracking, catalytic cracking and pyrolysis) can be used to produce biodiesel.

The classic biodiesel, named Fatty Acid Methyl Esther (FAME), is produced from triglycerides of raw vegetable oils, animal tallow and waste oil by conventional transesterification technologies, with basic, acidic, enzymatic or heterogeneous catalysts [16-22].

Biodiesel has: an adequate cetane number, biodegradability, lower toxicity, carbon neutral and eco-friendly fuel which produces: less sulphur, HC, PM, and CO emissions [23]. As compared with fossil diesel, biodiesel FAME type has: lower energy content, higher viscosity, augmented $\mathrm{NO}_{\mathrm{X}}$ emissions, higher pour point and cloud point [24].

Together with FAME the transesterification reaction produces glycerol at a volumetric ratio of 10/1. Glycerol still remains a barrier in biodiesel production. Analysing an impressive number of scientific articles, databases and patents, Monteiro [25] identifies 4 major directions for glycerine capitalization:

-Manufacture of chemical product;

-Production of polymers;

-Production as biofuels and biogas;

-Purification and use as glycerol.

Despite FAME higher production costs compared with fossil fuels, it is estimated that biodiesel production will grow to 41 million $\mathrm{m}^{3}$ in 2022 [25]. This growth will be encouraged through government policies, constraints on environmental legislation and fiscal policies.

*email: prosca@upg-ploiesti.ro 
Moreover, the efficient valorisations of glycerol can maintain the biodiesel type FAME in biofuels competition. At the same time, hydroconversion of triglycerides from vegetable oils and animal fats can be an alternative way to produce biodiesel named Renewable Diesel (RD) [26-32].

In comparison with FAME production by transesterification the hydroconversion process to produce RD has the following advantages:

- Compatibility of the RD with existing engines;

- Feedstock flexibility regarding the content of free FAs;

- $\quad$ Free of by-product (glycerol).

Also, the RD biofuel has superior characteristics such as: higher cetane number, higher oxidation stability, higher energy, $0 \%$ oxygen content than FAME, negligible sulphur and aromatics [33].

The main limitation in biofuel fabrication is the direct competition with the usage of biomass for food production.

A solution to this problem is to use the waste of: cooking oil, animal fats and industrial used oils as raw materials for the production of biofuel, reducing significantly the overall price [34-36], as well as the environmental pollution effects caused by storage. A significant resource of non-food oil can be the oil obtained from fish waste. For centuries, fish and secondary products out of fish, have been consumed as food for humans and animals.

Humans consume just a small amount of the total annual caught fish, while the rest is used as animal food or in industry in order to fabricate: fodder, soap, glycerine or other non-food products. Fish processing results in considerable waste quantities which is a major problem for the storage and for environmental protection.

A beneficial solution is processing the fish waste into different FO sorts: a) black-brown colour raw oil, very viscous with powerful odour or b) transparent refined oil resulting from the extraction of omega FAs, with a low viscosity and less odour. The most common FO obtaining method is the wet reduction in three steps: cooking at high temperature (85$95^{\circ} \mathrm{C}$ ), pressing and centrifuging. Other alternative methods are: hydraulic pressing, vacuum distillation, urea crystallization, hexane solvent extraction and conventional crystallization [37]. The oil obtained as a sub-product from fish processing, can be used as raw material for production of diesel type biofuel.

The objective of the present paper is to utilize the FO obtained as a by-product resulting from fish wastes processing for the production of diesel type biofuels through hydrotreatment. The FO and FO mixed with SRGO have been subjected to hydro-treatment reactions. The experiments aimed to establish the influence of the hydrotreatment process parameters over the characteristics of the obtained bio-diesel. Two types of catalysts have been used for the hydroprocess: $\mathrm{CoMo} / \mathrm{Al}_{2} \mathrm{O}_{3}$ and $\mathrm{CoMoRe} / \mathrm{Al}_{2} \mathrm{O}_{3}$.

\section{Experimental part \\ Materials}

For the experimental study, a FO (Nutrivet wild salmon) and SRGO were used. Table 1 presents the main characteristics of FO and SRGO and Table 2 shows the composition of FAs of FO.

Table 1

CHARACTERISTICS OF FO AND SRGO

\begin{tabular}{|c|c|c|c|c|}
\hline Characteristics & $\begin{array}{c}\text { Density at } \\
\mathbf{2 0}\end{array}$ & $\begin{array}{c}\text { Viscosity at } \\
\mathbf{4 0}\end{array}$ & Pour Point & Flash point \\
\hline Units & $\mathrm{g} / \mathrm{cm}^{3}$ & $\mathrm{~mm}^{2} / \mathrm{s}$ & ${ }^{\circ} \mathrm{C}$ & ${ }^{\circ} \mathrm{C}$ \\
\hline SRGO & 0.845 & 4.41 & -12 & 64.1 \\
\hline FO & 0.896 & 12.60 & 4 & 164.0 \\
\hline
\end{tabular}

Table 2

THE CHEMICAL COMPOSITION OF FO

\begin{tabular}{|c|c|c|c|}
\hline Peak & RT & Scientific name of acid & $(\%)$ wt \\
\hline 1 & 12.566 & myristic & 1.88 \\
\hline 2 & 15.890 & palmitoleic & 2.58 \\
\hline 3 & 16.317 & palmitic & 8.71 \\
\hline 4 & 19.742 & linoleic & 14.90 \\
\hline 5 & 19.966 & oleic & 48.33 \\
\hline 6 & 20.345 & stearic & 2.96 \\
\hline 7 & 23.121 & cis $5,8,11,14,17$ eicosapentaenoic & 2.86 \\
\hline 8 & 23.493 & $8,11,14,17$, eicosatetraenoic & 1.07 \\
\hline 9 & 23.764 & cis 11,14, eicosadienoic & 1.80 \\
\hline 10 & 23.900 & cis 11 eicosenoic & 5.85 \\
\hline 11 & 26.798 & $4,7,10,13,16,19$ docosahexaenoic & 4.45 \\
\hline 12 & 27.068 & $7,10,13,16,19$ docosaeptaenoic & 1.58 \\
\hline 13 & 27.746 & 13 docosenoic (erucic) & 3.03 \\
\hline
\end{tabular}


In order to determine the composition of FAs, the FO was esterified with methanol and then was subjected to gas chromatography / mass spectrometry analysis on a CP-3800 Triple Quad Agilent Technologies GC-MS system a NIST library was used to identify and analyse the reaction mixtures and the used parameters are presented in Table 3.

The result of the GC / MS analysis of FO is shown in Figure 1.

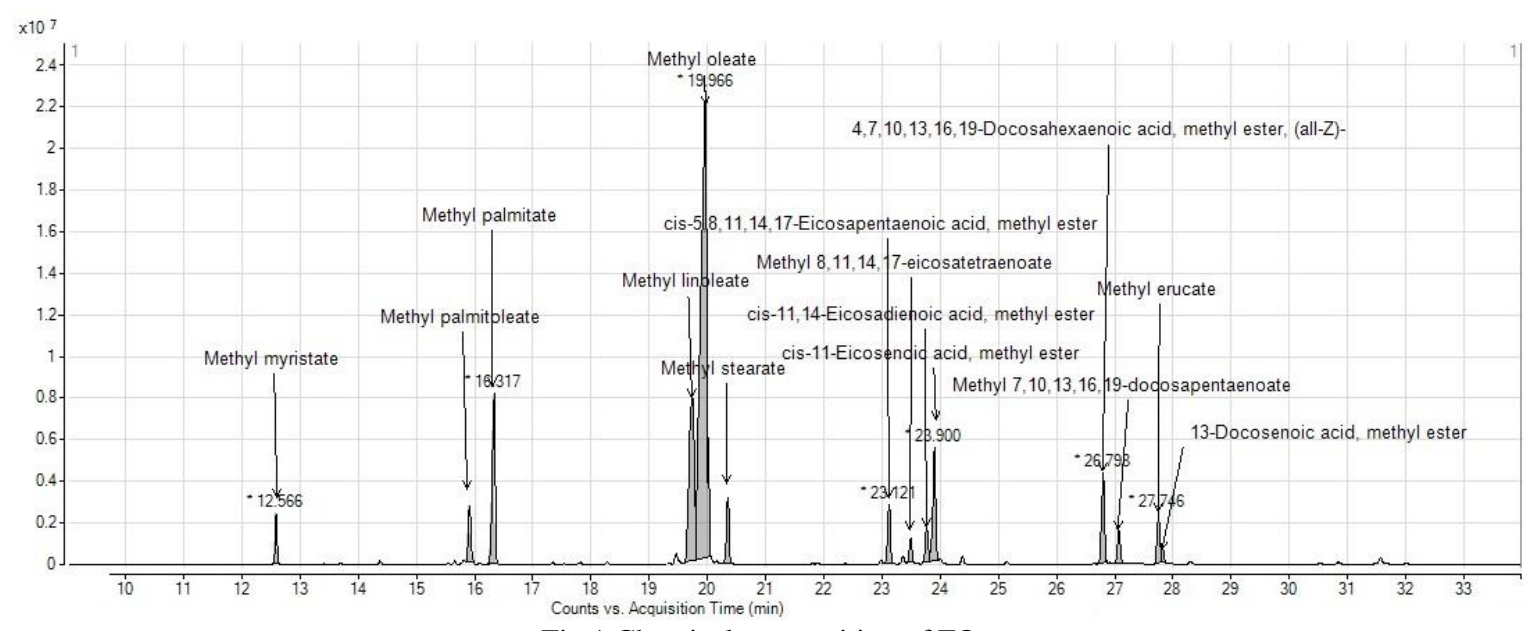

Fig.1.Chemical composition of FO

Table 3

THE PARAMETERS FOR GS/MS ANALYSIS

\begin{tabular}{|c|c|}
\hline GS Method & MS Method \\
\hline Column DB-WAX $(\mathrm{L}=30 \mathrm{~m}, \mathrm{D}=250 \mu \mathrm{m}, \mathrm{d}=0.25 \mu \mathrm{m})$ & $\begin{array}{c}\text { Collision cell QQQ: Flow Quench Gas }(\mathrm{He})=2.2 \\
\mathrm{ml} / \mathrm{min} \text {; collision gas flow }(\mathrm{N} 2)=1.5 \mathrm{ml} / \mathrm{min} ;\end{array}$ \\
\hline Oven program: $50^{\circ} \mathrm{C}$ for $1 \mathrm{~min}$. , then $7{ }^{\circ} \mathrm{C} / \mathrm{min}$. until $180^{\circ} \mathrm{C}$ & Source type: $\mathrm{EI} ;$ \\
\hline Carrier gas: $\mathrm{He}$, debit $1 \mathrm{ml} / \mathrm{min}$ & Electrons energy: $70 \mathrm{eV} ;$ \\
\hline Injector temperature: $250^{\circ} \mathrm{C}$ & $\begin{array}{c}\text { Source temperature: } 230^{\circ} \mathrm{C} ; \\
\text { Temperature Aux } 2: 280^{\circ} \mathrm{C}\end{array}$ \\
\hline
\end{tabular}

Two catalysts were used, $\mathrm{CoMo} / \mathrm{Al}_{2} \mathrm{O}_{3}$ type and $\mathrm{CoMoRe} / \mathrm{Al}_{2} \mathrm{O}_{3}$ type obtained by successive impregnations with aqueous solutions of the catalytic precursors, applying the method of filling the support pores. Catalyst precursors were cobalt nitrate $\mathrm{Co}\left(\mathrm{NO}_{3}\right)_{2}$, ammonium heptamolybdate tetrahydrate $\left(\mathrm{NH}_{4}\right)_{6} \mathrm{Mo}_{7} \mathrm{O}_{24} 4 \mathrm{H}_{2} \mathrm{O}$ and perrhenic acid $\left(\mathrm{H}_{4} \mathrm{O}_{9} \mathrm{Re}_{2}\right)$, respectively. The precursor concentrations from impregnation solutions were calculated according to the proposed metal content $(4 \% \mathrm{Co}, 8 \% \mathrm{Mo})$, respectively $(4 \% \mathrm{Co}, 8 \% \mathrm{Mo}, 0.5 \% \mathrm{Re})$ as well as the catalyst support pore volume.

Catalysts reconditioning between impregnations has been carried out by oven drying at $160^{\circ} \mathrm{C}$ for 4 hours and the final conditioning has been completed in the following sequence: 1) Oven drying at $160^{\circ} \mathrm{C}$ for 8 hours; 2) Calcination at $450^{\circ} \mathrm{C}$ for 6 hours, followed by activation in a hydrogen stream at $450^{\circ} \mathrm{C}$ for 6 hours. The chemical composition of the catalysts used in the experiment was confirmed by atomic absorption. Catalysts textural data (specific surface, pore volume, mean pore diameter, pore size distribution) were determined on an Autosorb1 Quantacrome (Table 4). The texture data were obtained by automatic recording and processing of the adsorption-desorption nitrogen isotherms. The specific surface was calculated using the BET equation in the linear part of the adsorption isotherm. To evaluate the pore distribution and the pore size, desorption branch of the isothermal with hysteresis was used applying the $\mathrm{BJH}$ method.

The adsorption isotherms for the prepared catalysts (Fig. 2) are V type with a $\mathrm{H} 3$ loop hysteresis characteristic of mesoporous materials, with low affinity for the adsorbed molecules and a tight distribution of the pore size. The specific surface of the two catalysts has a typical value for $\gamma$-alumina catalysts. Thus, the specific surface is relatively large, the volume of the pores is large and the distribution of the mesoporous sizes indicates a good accessibility of the active centres, compatible with the FO triglycerides diameter.

Table 4

PHYSICAL PROPERTIES OF CATALYSTS

\begin{tabular}{|c|c|c|}
\hline Property & $\mathbf{C o M o} / \mathbf{A l}_{2} / \mathbf{O}_{3}$ & CoMoRe/Al $\mathbf{O}_{\mathbf{3}}$ \\
\hline Surface area $\left(\mathrm{m}^{2} / \mathrm{g}\right)$ & 274.145 & 257.162 \\
\hline Pore volume $\left(\mathrm{cm}^{3} / \mathrm{g}\right)$ & 0.486 & 0.466 \\
\hline Average pore size $(\mathrm{nm})$ & 6.300 & 6.400 \\
\hline
\end{tabular}

$\mathrm{BJH}$ pore size distribution reveals that the two catalysts contain a trimodal pore size distribution at an average pore distribution of $5.2 \mathrm{~nm}, 6.3 \mathrm{~nm}$ respectively $7.5 \mathrm{~nm}$. 

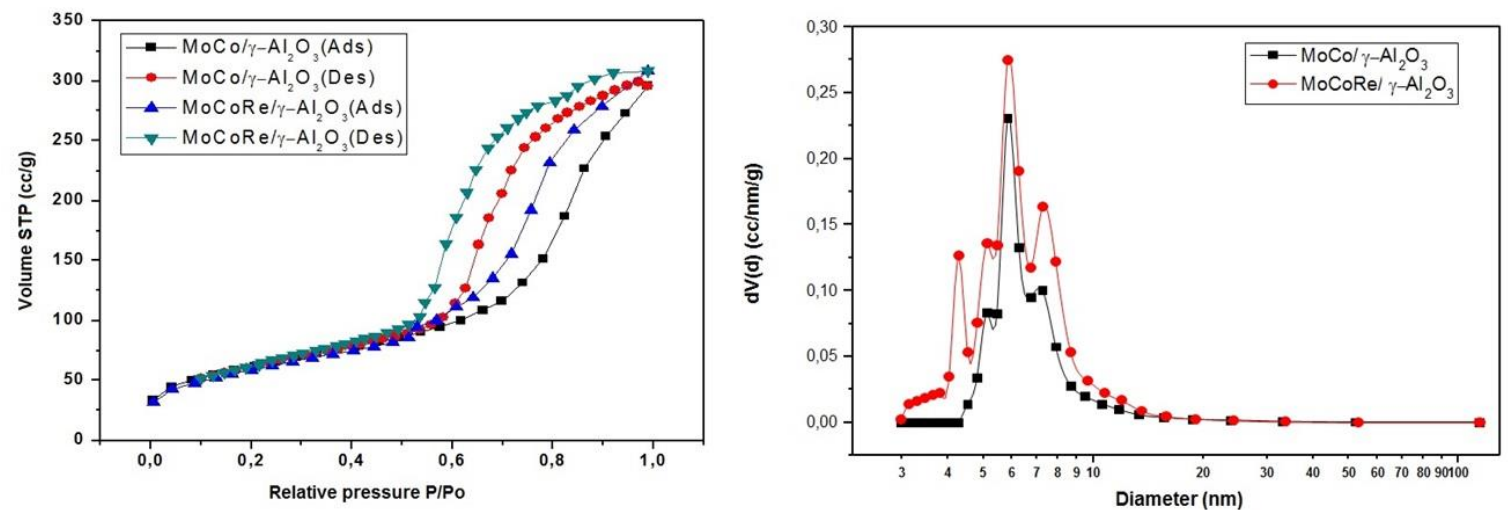

Fig. 2. $\mathrm{N}_{2}$ adsorption isotherms of catalysts

The catalysts were activated by sulfurization with dimethyl-disulphide (DMDS) solubilized in SRGO, to 4\%wt concentration, in the presence of hydrogen at a flow rate of $151 / \mathrm{h}, 280^{\circ} \mathrm{C}$ and $15 \mathrm{bar}$. Activation is completed after the $\mathrm{H}_{2} \mathrm{~S}$ formation in the reaction gases is revealed at the appearance of the yellow colour of cadmium acetate 5\% aqueous solution, used as indicator.

\section{Micro-pilot plant}

The hydrotreating experiments were performed on a micro-pilot plant (Fig. 3) by using a fixed bed reactor with a volume of $40 \mathrm{~cm}^{3}$.

The hydrotreating experiments have been carried out for, $\mathrm{FO}$ and a mixture of $\mathrm{FO}$ with 5 and $10 \% \mathrm{SRGO}$ at $380^{\circ} \mathrm{C}$ and 50bar with hourly space velocity $1.5 \mathrm{~h}^{-1}$ and $1000 \mathrm{~cm}^{3} / \mathrm{cm}^{3} \cdot \mathrm{H}_{2} /$ feedstock ratio.

The experiments ran for 3 hours. The liquid phase is dried with $\mathrm{CaCl}_{2}$ in order to remove the traces of water, as a result of FO FAs deoxygenation reactions and then it is weighed to establish the yield in hydrotreated product.

The chemical composition of the liquid product obtained from FO hydrotreating, was determined by GS/MS on a GC-MS CP-3800 Triple Quad Agilent Technologies. Biofuel resulting from hydrotreatment was characterized to determine: density (EN ISO 12185), pour point (SR 13552), flash point (SR 5489) and viscosity (SR EN ISO 3104)

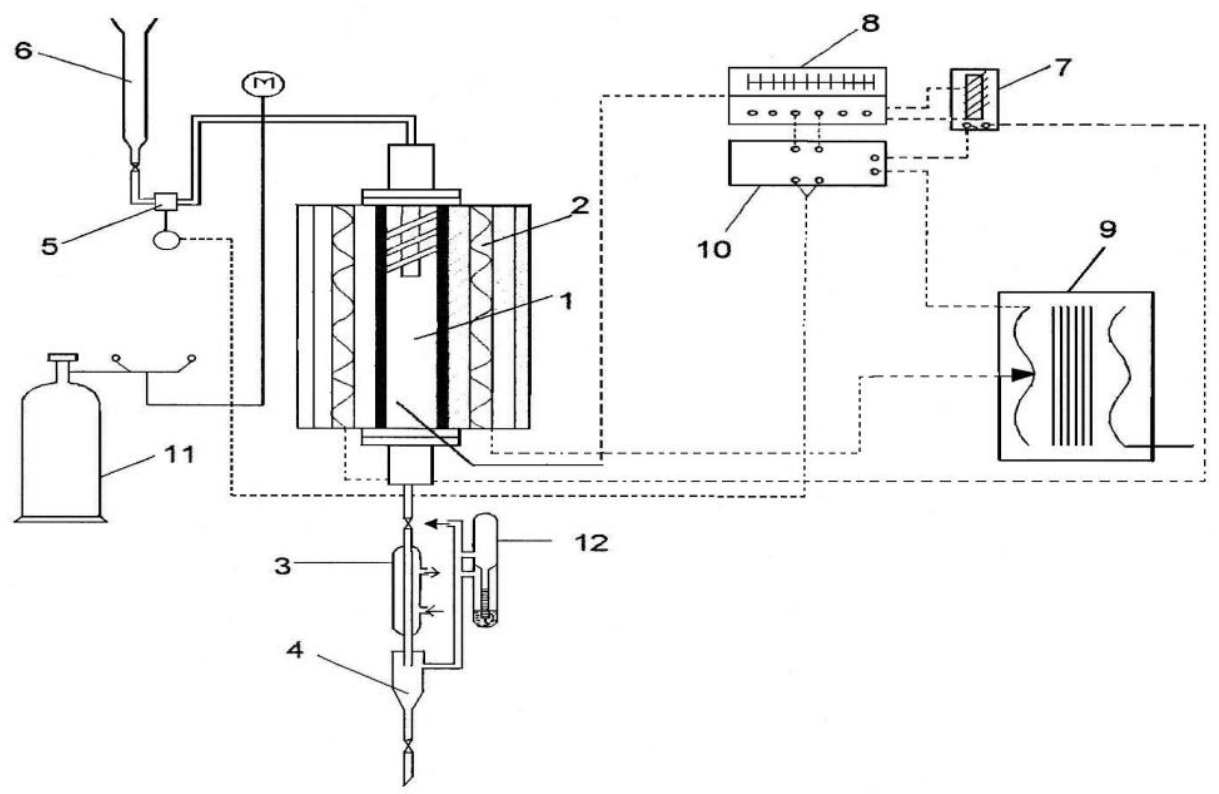

Fig. 3.The Hydrotreating Micro-pilot Plant

(1-reactor, 2-electrical furnace, 3-water cooler, 4-liquid-gas separator, 5-metering pump, 6-feedstock burette 7-relay, 8- temperature register, 9-autrotransformer, 10-temperature controller, 11-hydrogen tank, 12-flow meter)

\section{Results and discussions}

As shown in Table 2 the FO used in the hydrotreatment process contains $13.55 \%$ wt of saturated FAs, 59.79\%wt monounsaturated and $26.66 \% \mathrm{wt}$ polyunsaturated FAs. The saturated FAs contain mainly palmitic acid and the unsaturated ones, oleic acid. Distribution by number of carbon atoms highlights the very high content of FAs with 18 carbon atoms $(66.19 \%)$, followed by 20 atoms $(11.58 \%)$ and 16 atoms $(8.71 \%)$. The material balance for each experience is presented in Table 5 . 
The yields in the products were determined by the mass balance for each experiment, as a result of knowing the amount of raw material and of weighing the organic product resulting from hydrotreatment, after water absorption on $\mathrm{CaCl}_{2}$. The gases were established by difference.

Table 5

PRODUCTS YIELDS OBTAINED BY HYDROCONVERSION OF FO AND OF FO WITH SRGO MIXTURES

\begin{tabular}{|c|c|c|c|c|c|c|}
\hline Catalyst & \multicolumn{3}{|c|}{$\mathrm{CoMo} / \mathrm{Al}_{2} \mathrm{O}_{3}$} & \multicolumn{3}{|c|}{$\mathrm{CoMoRe} / \mathrm{Al}_{2} \mathrm{O}_{3}$} \\
\hline $\begin{array}{c}\text { FO content in mixture } \\
\text { FO-SRGO }(\%)\end{array}$ & 5 & 10 & 100 & 5 & 10 & 100 \\
\hline Hydrotreated Product & 95.47 & 94.65 & 84.94 & 96.38 & 94.12 & 84.09 \\
\hline Gas & 4.05 & 4.44 & 6.14 & 3.08 & 4.76 & 5.85 \\
\hline Water & 0.48 & 0.91 & 8.92 & 0.54 & 1.12 & 10.06 \\
\hline
\end{tabular}

Hydroconversion of FO alone determined lower hydrotreated product yields, due to water and gas (propane, $\mathrm{CO}$, $\mathrm{CO}_{2}$ ) formation. This is due to hydrocracking of triglycerides and hydrodeoxygenation, hydrodecarbonylation and hydrodecarboxylation reactions of FAs. Hydrodeoxygenation reactions favoured by the more acidic CoMoRe catalyst generate more water. In the hydroconversion of SRGO mixtures with 5\% and $10 \%$ of FO respectively, the yields in the hydrotreated liquid product are higher, than in the case of hydrogenation of FO alone. SRGO does not contain oxygen compounds and gases originate only as a result of the hydrogenation of the compounds with sulphur and nitrogen and of the hydrocracking reactions.

Decreasing yields are accentuated by an increase in the proportion of FO added ratio to the SRGO, as a result of FA content increase, which generates more water and gases through hydroconversion reactions.

The chemical composition of the bio-oil resulting from the hydrotreating of $\mathrm{FO}$ on $\mathrm{CoMo} / \mathrm{Al}_{2} \mathrm{O}_{3}$ and $\mathrm{CoMoRe} / \mathrm{Al}_{2} \mathrm{O}_{3}$ catalysts was determined by the GC-MS method and is shown in Tables 6, 7 and Figures 4, 5.

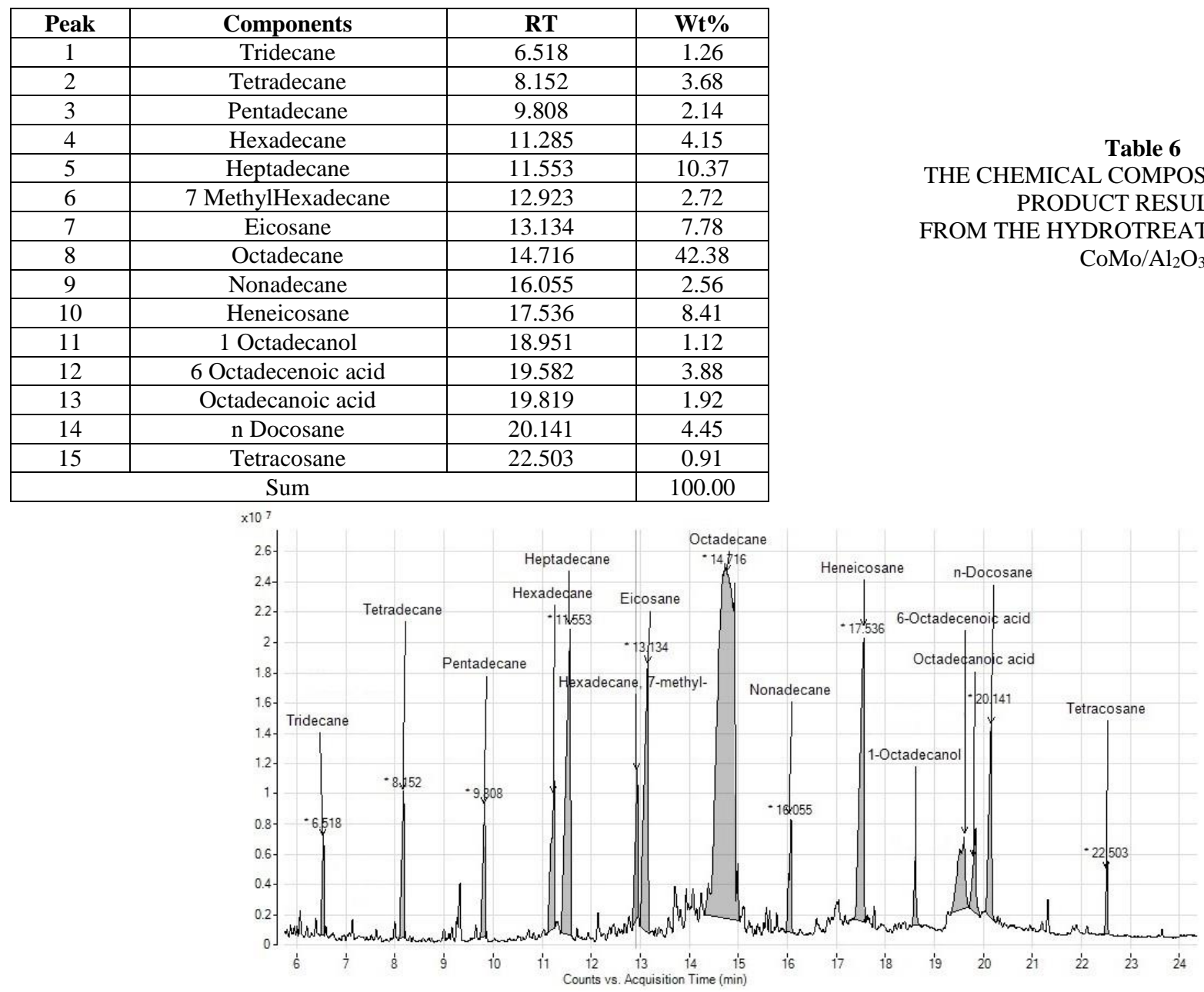

Fig.4.Chemical composition of hydrotreated biofuel on $\mathrm{CoMo} / \mathrm{Al}_{2} \mathrm{O}_{3}$ catalyst 
Table 7

CHEMICAL COMPOSITION OF PRODUCT RESULTING

FROM HYDROTREATING OF FO ON A CoMoRe/ $/ \mathrm{Al}_{2} \mathrm{O}_{3}$

\begin{tabular}{|c|c|c|c|}
\hline Peak & Components & RT & Wt \% \\
\hline 1 & Tridecane & 6.648 & 0.75 \\
\hline 2 & Tetradecane & 7.874 & 1.72 \\
\hline 3 & Pentadecane & 9.160 & 3.73 \\
\hline 4 & Hexadecane & 10.595 & 8.62 \\
\hline 5 & 7 MethylHexadecane & 11.245 & 2.26 \\
\hline 6 & 4 MethylPentadecane & 11.347 & 0.55 \\
\hline 7 & 4 methylHexadecane & 11.449 & 0.52 \\
\hline 8 & 8 HexilHentadecane & 11.550 & 0.50 \\
\hline 9 & 3 MethylHexadecane & 11.679 & 0.43 \\
\hline 10 & Heptadecane & 12.214 & 16.19 \\
\hline 11 & 8 MethylHeptadecane & 12.891 & 4.61 \\
\hline 12 & 7 HexilTridecane & 12.952 & 1.39 \\
\hline 13 & 8 HexylPentadecane & 13.020 & 1.32 \\
\hline 14 & 3 Methyl Heptadecane & 13.135 & 1.43 \\
\hline 15 & 2 Methyl Heptadecane & 13.250 & 1.16 \\
\hline 16 & 4 MetilHeptadecane & 13.392 & 1.39 \\
\hline 17 & Octadecane & 14.022 & 36.82 \\
\hline 18 & 1 Octadecanol & 15.166 & 1.17 \\
\hline 19 & 2 DodecylCiclohexane & 15.274 & 1.39 \\
\hline 20 & n Dodecyl Benzene & 15.626 & 0.97 \\
\hline 21 & Eicosane & 15.802 & 3.42 \\
\hline 22 & Heneicosane & 17.786 & 6.35 \\
\hline 23 & Docosane & 21.829 & 3.31 \\
\hline & Sum & 100.00 \\
\hline
\end{tabular}

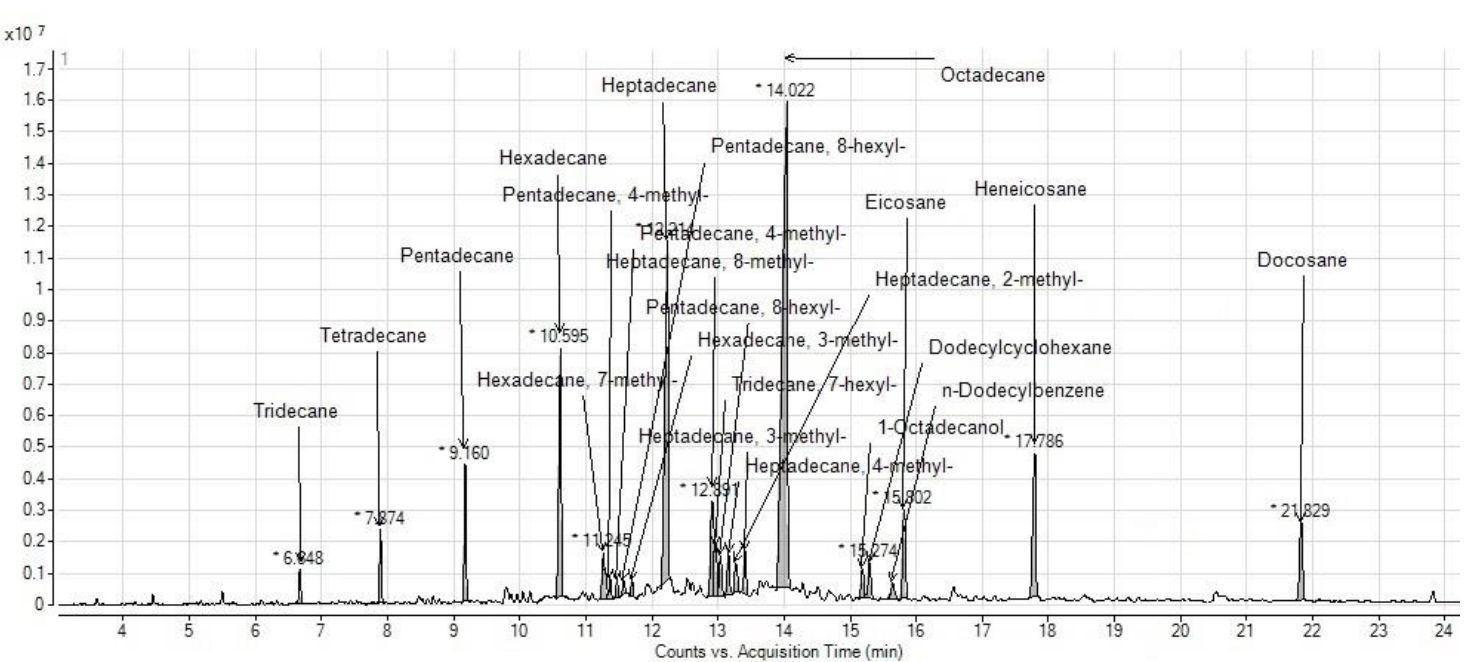

Fig. 5. Chemical composition of hydrotreated biofuel on CoMoRe/ $/ \mathrm{Al}_{2} \mathrm{O}_{3}$ catalyst

The data presented in Tables 6, and 7 demonstrate that the hydrotreating of FO results mainly in obtaining paraffin with the same number of carbon atoms as FAs as a consequence of triglycerides transformation from oil, by hydrodeoxygenation reactions and paraffin with a less carbon atom as a result of hydrodecarboxylation or hydrodecarbonilation reactions. In all three mentioned reactions: propane, $\mathrm{CO}_{2}, \mathrm{CO}$ and water are generated Figure 6 shows a general scheme of reactions occurring in the FO hydroconversion process.

The triglyceride double bonds are hydrogenated and then by hydrocracking, triglycerides break down with propane and free FAs formation, which after that, through a series of reactions indicated in the scheme, they convert to normal and isoparaffin with 13-22 carbon atoms, which can constitute components for fuel formulation. FAs with 18 carbon atoms (66.19\%) are transformed by hydrodeoxygenation into: $42.38 \%$ octadecane on the CoMo and $43.91 \%$ octadecane on CoMoRe (Fig. 7).

Taking into consideration the low content in acids with 17-carbon atoms (2.58\%), most of the C17 paraffin come from the hydrodecarbonylation and hydrodecarboxylation reactions of acids with 18 carbon atoms. Also, by hydrocracking and isomerization reactions, facilitated by the acidity of the catalyst, paraffin with fewer carbon atoms and isoparaffin respectively, are produced. In addition to the support acidity $\left(\mathrm{Al}_{2} \mathrm{O}_{3}\right)$, Rhenium added to the catalyst as perrhenic acid $\left(\mathrm{H}_{4} \mathrm{O}_{9} \mathrm{Re}_{2}\right)$, increases its acidity (generating Lewis acid centres). Higher acidity justifies formation by 
isomerization reactions of branched paraffin in a proportion of $15.36 \%$ on the CoMoRe catalyst compared to only $2.72 \%$ on the CoMo type.

The presence of alkyl cyclohexane (2-dodecylcyclohexane) and alkyl benzenes (n-dodecylbenzenes) is explained by cyclization and dehydrogenation reactions of olefin-like intermediate products, which occur in the cracking reactions on the acidic centres of the catalyst.

The lower hydrogenation activity of the $\mathrm{CoMo} / \mathrm{Al}_{2} \mathrm{O}_{3}$ catalyst compared to the CoMoRe type, justifies the presence of FAs and fatty alcohols (octadecanoic acid, 6-octadecenoic acid and octadecanol) in the hydrotreated product.
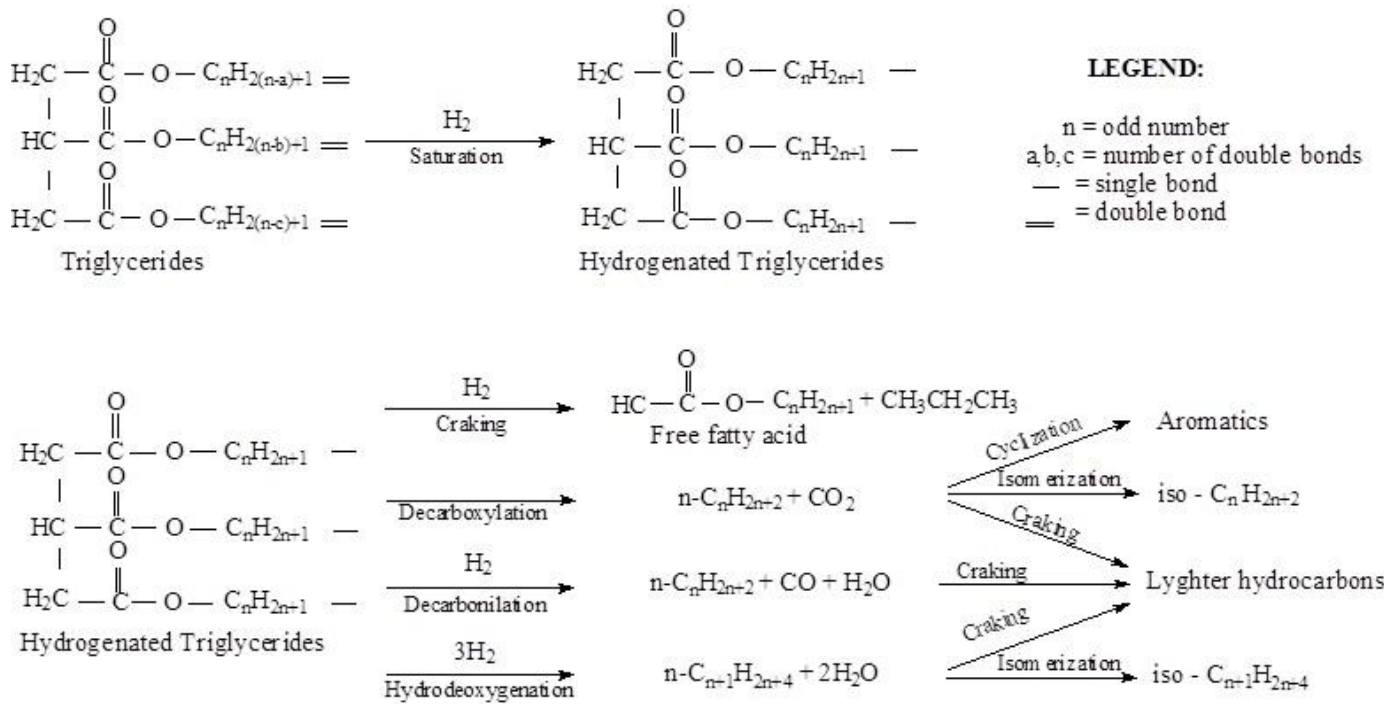

Fig. 6. Hydroconversion of FO into Biofuel Scheme

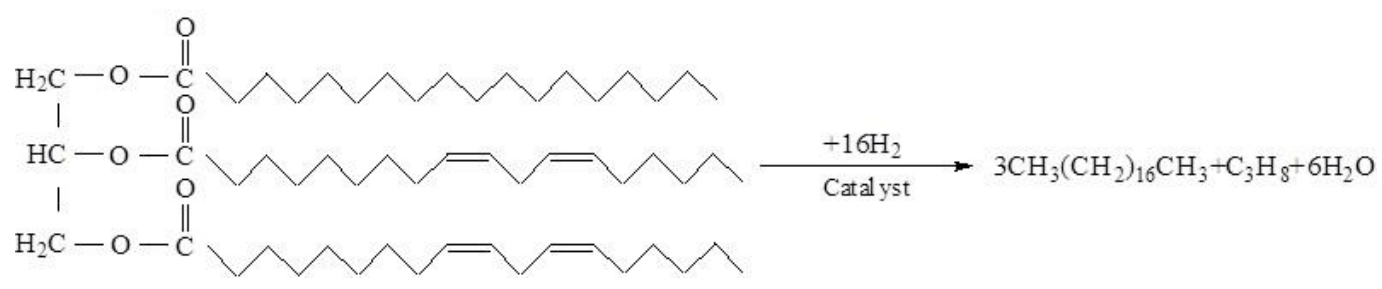

Fig. 7. Hydrodeoxygenation of C18 FA Scheme

The hydrotreatment experiments aimed to convert the FO into a bio component for diesel fuel and to directly obtain bio fuel by hydrotreating of FO-SRGO mixtures. The main physicochemical characteristics of liquid product, resulting from hydrotreatment are shown in Table 8.

Table 8

PHYSICOCHEMICAL PROPERTIES OF THE HYDROTREATED PRODUCT

\begin{tabular}{|c|c|c|c|c|c|c|}
\hline Catalyst & \multicolumn{3}{|c|}{$\mathrm{CoMo} / \mathrm{Al}_{2} \mathrm{O}_{3}$} & \multicolumn{3}{|c|}{$\mathrm{CoMoRe} / \mathrm{Al}_{2} \mathrm{O}_{3}$} \\
\hline $\begin{array}{c}\text { FO content in mixture } \\
\text { FO-SRGO }\end{array}$ & 5 & 10 & 100 & 5 & 10 & 100 \\
\hline \multicolumn{7}{|c|}{ Properties } \\
\hline Density $\left(\mathrm{g} / \mathrm{cm}^{3}\right)$ at $15^{\circ} \mathrm{C}$ & 0.8423 & 0.8396 & 0.8037 & 0.8407 & 0.8381 & 0.7928 \\
\hline Viscosity $\left(\mathrm{mm}^{2} / \mathrm{s}\right)$ at $40^{\circ} \mathrm{C}$ & 3.92 & 3.78 & 3.59 & 3.86 & 3.74 & 3.21 \\
\hline Flash Point, $\left({ }^{\circ} \mathrm{C}\right)$ & 77 & 71 & 58 & 79 & 73 & 54 \\
\hline Pour Point, $\left({ }^{\circ} \mathrm{C}\right)$ & -10 & -7 & 4 & -14 & -13 & -8 \\
\hline
\end{tabular}

The physicochemical characteristics of the hydrotreated product are influenced by the FO content in mixture FOSRGO as well as by the catalyst used.

Table 8 data reveal a significant decrease in the hydrotreated FO density $\left(0.7928\right.$ or $0.8037 \mathrm{~g} / \mathrm{cm}^{3}$ respectively $)$ vs the density of the crude FO $\left(0.896 \mathrm{~g} / \mathrm{cm}^{3}\right)$ as a result of the hydrogenation reactions which eliminate the groups containing oxygen from the oil structure [31]. The products resulting from the hydroconversion of FO and FO-SRGO blends have 
densities ranging from 0.8381 to $0.8423 \mathrm{~g} / \mathrm{cm}^{3}$, within the limits imposed by the EN590 standard for diesel fuel (density $\left.0.820-0.845 \mathrm{~g} / \mathrm{cm}^{3}\right)$. The conversion of FO into a mixture of mostly paraffinic hydrocarbons, with a lower density in relation to the other hydrocarbon classes, with the same number of carbon atoms as hydrotreated gas oil, explains the decreasing of the hydrotreated product density, along with the increasing of the added ratio. Due to the higher acidity, which intensifies the hydrocracking reactions, by hydroconversion on the CoMoRe catalyst, there results biofuels of a lower density as compared to CoMo catalyst case.

Rhenium doped catalyst allows a slight improvement of the properties due to the n-paraffin hydroisomerization reactions. Thus, the pour point decreases from $4^{\circ} \mathrm{C}$ for mixtures with $5 \% \mathrm{FO}$ to $6^{\circ} \mathrm{C}$ for mixtures with $10 \% \mathrm{FO}$ and to $12^{\circ} \mathrm{C}$ for the hydrotreated FO (Table 3.7). The decrease is justified mainly due to the increasing in isoparaffin content, from $2.72 \%$ on the $\mathrm{CoMo} / \mathrm{Al}_{2} \mathrm{O}_{3}$ catalyst, to $15.36 \%$ on the most acidic CoMoRe/ $\mathrm{Al}_{2} \mathrm{O}_{3}$ catalyst, as a result of paraffin hydroisomerization reactions. Since the value of the cold flow properties are below EN 590 requirements, the following steps are suggested the hydroisomerisation of hydrotreated products on catalysts with higher acidity [28] and the adding of pour point depressants additives.

The transformation of triglycerides from FO, into paraffinic hydrocarbons with 13-22 carbon atoms in the molecule (Table 6,7), results in a significant decrease of product kinematic viscosity, obtained by hydroconversion from $12.6 \mathrm{~mm}^{2} / \mathrm{s}$ for pure FO to respectively $3.21 \mathrm{~mm}^{2} / \mathrm{s}$ and $3.59 \mathrm{~mm}^{2} / \mathrm{s}$ for the hydrotreated oils on the two catalysts.

Biofuel viscosity obtained from the hydrotreatment of FO-SRGO blends, decreases as compare to the viscosity of the two feedstocks up to values below $4.5 \mathrm{~mm}^{2} / \mathrm{s}$. Viscosity decrease is bigger for the more acidic CoMoRe catalyst.

The elimination of carboxyl bonds by hydrogenation of FAs, causes a significant decrease in the flash point, from $164^{\circ} \mathrm{C}$ for pure $\mathrm{FO}$ at $54-58^{\circ} \mathrm{C}$ for hydrotreated FOs.

\section{Conclusions}

Oil recovery from by-products obtained in the fish industry is a cost effective strategy for fuel production and it is also an efficient solution to the pollution problems generated by their storage.

Hydrotreatment of FOs is a technologically accessible and a cost-effective process for the production of diesel biofuels.

Hydrogenation of double bonds and carboxyl groups of FAs, accompanied by secondary hydrocracking and isomerization reactions, results in the formation of a predominantly paraffinic hydrocarbon mixtures with 13-22 carbons in the molecule with physicochemical characteristics in conformity with to the requirements of quality standard for diesel fuel EN590.

Hydrotreated product composition is strongly influenced by the catalyst acidity. The isoparaffins content is $15.36 \%$ on the more acidic CoMoRe/ $/ \mathrm{Al}_{2} \mathrm{O}_{3}$ type catalyst compared to $2.72 \%$ on the $\mathrm{CoMo} / \mathrm{Al}_{2} \mathrm{O}_{3}$ type.

Hydrotreatment of FO-SRGO mixtures with different FO content in mixture FO-SRGO is an efficient method to produce biofuels.

\section{References}

1. MRAD, N., VARUVEL, E.G., TAZEROUT, M., ALOUI F., Energy 44, (2012), p. 955-963.

2. USHAKOV, S., VALLAND, H., ĆŠ̌Y, V., Energy Conversion and Management 65, (2013),

p. $228-238$.

3. GÜLÜM, M. BILGIN, A., Fuel Processing Technology 134, (2015), p. 456-464.

4. MONYEM, A., VAN GERPEN, J.H., Biomass and Bioenergy 20, (2001), p. 317-325.

5. DWIVEDI, G., JAIN, S., SHARMA, M.P., Renewable and Sustainable Energy Reviews 15, (2011), p. 4633-4641.

6. TOMOS, B., NOVELLA, R., GARCIA, A., GARGAR, K., Renewable Energy 35, (2010), p. 368-378.

7. KARL, T.R., TRENBERTH, K.E., Science 302, (2003), p. 1719-1723.

8. DAHLQUIST, E., THORIN, E., YAN, J., International Journal of Energy Research 31, (2007), p. 1226-1236.

9. ESCOBAR, J.C., LORA, E.S., VENTURINI, O. YÁÑEZ, E. E. CASTILLO, E.F. ALMAZAN, O., 13, (2009), p. $1275-1287$.

10. MISRA, R.D., MURTHY, M.S., Renewable and Sustainable Energy Reviews 14, (2010), p. 3005-3013.

11. OPRESCU, E.E., STEPAN, E., DRAGOMIR, R.E., RADU, A., ROSCA, P., Fuel Processing Technology 110 , (2013), p. $214-217$.

12. NAUTIYAL, P., SUBRAMANIAN, K.A., DASTIDAR, M.G., Fuel Processing Technology 120, (2014), p. 79-88.

13. Romanian Energy Strategy 2016-2030, with perspectives for 2050, 15 november, 2016.

14. DEMIRBAS, A., Energy Conversion and Management 50, (2009), p. 14-34.

15. NIGAM, P.S., SINGH, A., Progress in Energy and Combustion Science 37, (2011), p. 52-68.

16. BEHÇET, R., YUMRUTAS, R., OKTAY, H., ENERGY 71, (2014), P. 645-655.

17. AGHBASHLO, M., TABATABAEI M., HOSSEINPOUR, S. Energy Conversion and Management 64, (2018), p. 385-398.

18. MA, F.R., HANNA, M.A., Bioresource Technology 70, (1999), p.1-15.

19. MATH, M.C., KUMAR S.P., CHETTY, S.V., Energy for Sustainable Development 14, (2010), p. 339-345.

20. MARCHETTI, J.M.,MIGUEL,V., ERRAZU, O.F., Renewable and Sustainable Energy Reviews 11, (2007), p. 1300-1311.

21. MEHER, L.C., SAGAR, D.V. NAIK S.N., Renewable Sustainable Energy Reviews 10, (2006), p. $248-268$.

22. HAMA, S., YAMAJI, H., KAIEDA, M., ODA, M., KONDO, A., FUKUDA, H., Biochemical Engineering Journal 21 , (2004), p. 155-160.

23. DEVENDRA, S., SUBRAMANIAN, K.A., GARG. M., Renewable and Sustainable Energy Reviews 81, (2018), p. $2947-2954$.

24. SAKTHIVEL, R., RAMESH, K., PURNACHANDRAM, P., SHAMEER, P,M., Renewable and Sustainable Energy Reviews 82, (2018), p. 2970-2992. 
25. MONTEIRO, R.M., KUGELMEIER, L.C., PINHEIROS, S.R., BATALHA O.M., CESAR, S.A., Renewable and Sustainable Energy Reviews 88, (2018), p. 109-122.

26. ANTUNES, W.M., VELOSO, C.O., HENRIQUES, C.A., Catalysis Today 133, (2008), p. 548-554.

27. DRAGOMIR, R.E., ROSCA, P., Rev. Chim. (Bucharest) 65, 2014, p. 485-488.

28. DRAGOMIR, R.E., ROSCA, P., OPRESCU, E.E., Rev. Chim. (Bucharest) 65, 2014, p. 616-619.

29. J. WALENDZIEWSKI, J., STOLARSKI, M., LUZNY, R., KLIMEK, B., Fuel Processing Technology 90, (2009), p. 686-691.

30. GUSMAO, J., BRODZKI, D., DJEGA-MARIADASSOU, G., FRETY, R., Catalysis Today 5, (1989), p. 533-544.

31. KUBIČKOVÁ, I., SNÅRE, M., ERÄNEN, K., MÄKI-ARVELA, P., MURZIN, D.Y., Catalysis Today 106, (2005), p.197-200.

32. BEZERGIANNI, S., KALOGIANNI, A., VASALOS, I., Bioresource Technology 100, (2009,) p. 3036-3042.

33. SINGH, D., SUBRAMANIAN, A.K., GARG, O.M., Renewable and Sustainable Energy Reviews 81, (2018), p. $2947-2954$.

34. BEZERGIANNI, S., KALOGIANNI, A., Bioresource Technology 100, (2009), p. 3927-3932.

35. ZHANG, Y., DUBÉ, M.A., MCLEAN, D.D., KATES, M., Bioresource Technology 90, (2003), p. 229-240.

36. DRAGOMIR, R.E., ROSCA, P., JUGANARU, T. OPRESCU, E.E., Rev. Chim. (Bucharest), 66, 2015, p. $277-281$.

37. RUBIO-RODRÍGUEZ, N., DIEGO, S.M., BELTRÁN, S., JAIME, I., SANZ, M.T., ROVIRA, J., Journal of Food Engineering 109, (2012), p. $238-248$.

Manuscript received: 18.01 .2019 
